\title{
The Existence of Corruption Eradication Commission in The Criminal Law Reform in Indonesia
}

\author{
Ruslan Renggong \\ Lecturer of Law Faculty Universitas “45” Makassar Indonesia
}

\begin{abstract}
Criminal Law reform by unification and codification of the criminal law is very urgent for the need of improvement of sociaty. This becomes a serious problem in the offer of Law Criminal reform, as the government doesn't pay attention to the existence of the corruption Eradication commission. As the result, in the draft bill of the criminal code and the criminal procedural code, it is found certain subjects which crippling the power and the function of the corruption Eradication Commission. The crimes of corruption as the result of the Indonesia collapse in field of economic, politic, and social before and after the reformation in 1998. It can not be solved by simple ways. It needs to be held in a specific way. That's, all kind of rules which will cripple the Corruption Eradication Commission will be revised. The crime of corruption kept as the special crime which the basic rules of it will not be included in the criminal code and the special power of the corruption eradication commission will not be ruled in the criminal procedural code, but will be ruled in the corruption eradication commission code. That the government and the newly elected representatives house members must revoke the draft bill of the criminal code and the criminal procedural code which has been sent to the old reperesentatives to be revised and to be adjusted with the need and the hope of the people in order to against the corruption.
\end{abstract}

Key words: Existence-Corruption Eradication Commission-Criminal Law Reform

\section{INTRODUCTION}

Reformation in 1998 which bring down the corrupt, colutive, and nepotism Soeharto regim, inspired the Corruption Eradication Commission formulated. The Corruption Eradication Commission formulated to fulfill the agenda of reformation eradicate corruption in Indonesia by eradicating the corruption from the lowest level up to the top level of the government, including the Legislative and the Judicative Institution.

At the time, the law enforcer, such as the police and the judiciary, who has the power to eradicate the corruption that did not work effectively, so the corruption in the executor was very high. The Corruption Eradication Commission formulated showing a very significant result, but they can't eradicate totally the corrupt act of the executor yet. But then, by formulating The Corruption Eradication Commission the Indonesia corrupt index perception was getting lower according to transparency International in Berlin German.

Since The Corruption Eradication Commission formulated, hundreds of the Representatives House members, from the central level, Province level, Regency/city level, tens of governor, regent/major, judge, justicery, police, ex-miniters and many other executor have been suspected and have been punished. In 2014, there were three on job ministers accused by the Coruption Eradication Commission, they are the youth and sport minister, Religion Minister, and the Energy and The Human Resources minister. 
The Coruption Eradication Commission peformance was approved and appreciated by the Indonesian society as the government gave it the power more than the police and the justice. The Coruption Eradication Commission has the right to tap the corruption suspected conversation without any permission of the board of the Justicery and they are forbidden to stop any case on going. It means that the suspected must be sent to the court, this is different from the police on doing their case, they can stop the case but they are forbidden to tap the suspected conversation.

The successes to solve a case of corruption intangling the state executive in every level of government make the Coruption Eradication Commission get the public support. On the other hand the corrupt people hate this institution and it is shown in some modus to create the public opini that the Coruption Eradication Commission was not a clean nor law integrated institution.

This modus has been done many times by some oknums who want to demolish the Corruption Eradication Commission. They force the public to untrust this institution by criminating two of the commissioner of the Corruption Eradication Commission, like Chandra Hamzah and Bibit Waluyo. They were accused as if they had corrupted, nevertheless this was unproof. The effort of the people, who want to demolish the Corruption Eradication Commission as the weak justifier and has no public trusty, has been done by revising the policy no. 30 in the year of 2002 about Corruption Eradication Commission.

This revising was done due to reduce the special right of the Corruption Eradication Commission to eradicate the corruption such as eliminate the right to tap the corruption suspect conversation without of the board of the court, eliminate the right of prosecution of Corruption Eradication Commission, and reducing the operational budget of the Corruption Eradication Commission. But this modus was not success as the public were more and more trust this institution as the non-government, academician and the students.

After those unsuccess efforts to weaken the Corruption Eradication Commission, now there are other efforts of them called unification and codification of the criminal code and the criminal procedural code. At glance, those effort of the criminal code and the criminal procedural code renewal has no relationship with those efforts to weaken the Corruption Eradication Commission, but if we deeply take a look on the draft bill of the criminal code and the criminal procedural code we will find some chapters which weaken the Corruption Eradication Commission, because corruption crime will not be a special crime anymore, it will be general crime.

Based on the statements above, the writer put out the problem statement, as: how the effect of the criminal law reform to the existence of The Corruption Eradication Commission as the juriducery in Indonesia. The object of the research is aimed at knowing the effect of the unification and the codification of the criminal code and the criminal procedural code to the existence of The Corruption Eradication Commission as the juriducery in Indonesia. The purpose the research hope would be a good source to the government and the Representative House in the solution of the the draft bill of the criminal code and the criminal procedural code, and as the source to the next researcher who need to do the same research on the criminal code reform.

\section{RESEARCH METHODOLOGY}

The research was held in Makassar city the south Sulawesi Province Indonesia on July 2014 until September 2014. This research is descriptive normative-juridical research using primer 
and secunder law. The data are the draft bill of the criminal code and the criminal procedural code, the corruption eradication policy, the corruption eradication commission policy and other relevant literatures related to the research.

\section{DISCUSSION AND RESULT}

The reform of the Criminal Law especially of the Criminal Code and the Criminal Procedural Code are very urgent. The Criminal Code which was the product of the Dutch Colonialist in the book "Wet Boek van strafrecht" ruled based on "Koninklijke besluit" day Janury 1st 1915. This is very old and is not suit with the need and the demand of the Public Law. And as well as in The Criminal Procedural Code which was issued by the government of Indonesia 35 years ago. This is also out of date since there are so many changes in the Criminal Judicature process.

The big hope of the public on the issued of the unification and the codification of the Criminal Code as the main law of the Criminal Law and the unification and the codification of the Criminal Procedural Code as the main law of the Criminal Procedural comes to the right track after the draft of the Criminal Law and the draft of the Criminal Procedural sent to the Repsentatives House by the government to be discussed. Yet, the problem is still on because the draft of the Criminal Code which was defined spread in Chapter XXVIII, Chapter XXXXI, and Chapter XXXII with 23 verses on doing in injustice of corruption.

This shows that the designer of the draft of the Criminal Code has taken the corruption law norms out of the corruption law which is the specific crime into the Criminal Code which is the general crime. This also found in the draft of the Criminal Procedural Code has been included some regulation which directly weaken the Corruption Eradication Commission right to do its function in investigation and prosecution.

Below, will be examined some Chapter formula drafts:

\section{A. Chapter Formulas in the draft of the Criminal Code}

Substancially, the draft of the Criminal Code changed the corruption crime to public crime, it made this crime the same as the other crimes which arranged in the Crimnial Code and has no speciality in the norms and in the medium of the rulers. By changing this corruption crime into public crime omitted its "extra ordinary crime". Since corruption crime includes the politic right, social right, public economy right, destructive and this influence the state development programs. This also sistematically and endemically becomes social disorders.

As Corruption has already become a systematically and endemically social disorders, and transformed as an extraordinary injustice, an extraordinary way to solve is also needed (Lisnawati, 2013)

This idea is congruent with the judge Artidjo Alkotsar that corruption is different from other criminal. This is an extraordinary crime, which affects the future of the country and the public. It shows that the country is very rich but most of the people live in poverty. There are many begger on the road side, the economic democratic should be on the street seeing the rats cut off the public right. This corruption makes structurally poverty (Kompas, 2014)

Theoretically, effort and extraordinary means of eradication of corruption in the criminal law as follows: 1) the special rules in the criminal Law material such as; special rules in special assistance, trial, and arrangement of criminal system. 2) The special rules in the criminal Law procedural, like the special rights and Procedures, and 3) the existence of special institution such as the corruption eradication commission and the injustice crime court. The special effort 
and means which in point 1 and point 2 above, generally arranged in Penal Law, and now, those are arranged in corruption Penal Law.

a. Chapter 300, everyone breaks the law using any kind of tools listen to the others'conversation in or out side a house, room, or in the closed field, or by phone which is not in his right to listen, would be sentenced as long as 1 (one) year in jail or punishment in the category II. This chapter has been criminalized the tapping as it breaks the law. It means tapping must be done legally. This has not the same aim as the Corruption Eradication Commission practice. Based on the chapter 12 point a, corruption crime law, the investigating officer of the corruption eradication commission has the right to tap and to record the conversation of the suspects without any permission from the board of the court. This will minimize or even hamper the procedure and the right of the corruption eradication commission.

b. Chapter 702 , everyone who do criminal as in chapter 666 , chapter 667 , chapter 668 , chapter 670, chapter 671, chapter 688, chapter 689, chapter 690, chapter 691, chapter 693, chapter 694, chapter 695, chapter 696, chapter 697, chapter 698, chapter 699, chapter 700 and chapter 701as those inflicts the state financial loss, will be sentenced as those chapters determinations added with $1 / 3$ (one third). The consequency which result of the chapter 702 of criminal law code formulation is there not more formulation eradication corruption act as material crime that known in chapter 2 verse (1) and chapter 3 eradication corruption law. Corruption criminal act which known as the corruption that make the country lost and can be done by many ways which against the law such as; personal profit or for other people. The corruption can make lost of national economy. The law does not determine the types of criminal. Many people say that it is a common law and it has been done by the law practicioner.

By omitting the crimal cruption formulation about the lost country financial based on the some consideration as follow:

a. Draf bill criminal code has made a policy to formulate corruption criminal as formal criminal which formulated the type of criminal. It is a formal criminal that support the lex certa especially for the forbidden action. United Nations Convention against Corruption also uses the formulation action or cronologis of forbidden and unforbidden action.

b. When criminal is formulated materially, so it will make potencial bigger duplication.

c. Capter 3 verse 2 United Nations Convention against Corruption gives rules to criminalize corruption without see the lost of country financial and economy. Dismissing of the corruption criminal formulation get respons from the professor and criminal experts. The Forum discussion Group in several big cities in Indonesia, the professors of criminal law need the corruption crime still formulated materially. Based on the chapter 2 verse 1 and chapter 3 coruption crime laws. Some reason which discuss is the law histories of corruption in Indonesia "make lost of country financial and economy" become one of sociologist background or the reason to publish some regulation related to the corruption. Besides, the reality of corruption crime in Indonesia not only corruption but also corruption criminal which make the country big financial lost (Coruption Eradication Commission, 2014). The most important thing biside the normatve yuridical reason is omitted the corruption crimal in the chapter 2 verse 1 and chapter 3 coruption criminal law will cause the corruption criminal process when the draft of criminal code on discussing can be stopped. Even the criminal who has get punishment can be free. It is as consequence of the punishmen rule transitoir in 
chapter 3 verse 1 draf of criminal code when it is applied (Corruption Eradication Commission, 2014).

d. The chapter 757 point a, which determine the law that out of this law. It is given transition time for 3 years to be adapted to this law. Point $b$, after the transition time on the point a, so the crimal decision that out of this law be part to this law itself. The formulation of the desicion straighten up that there is not decision crime out of the criminal code. The impact of this decision is the doubt position of the Corruption Eradication Commission as a legal institution, and it will be broken automatically. Thus, when the draf of the criminal code is accepted by the Representative House members become a law, so the corruption eradication commitee authorities will be lost.

Related to the formulation of corruption crime law, the leader of the Corruption Eradication Commission, Abraham Samad (2014) says that crime as a part of the second book of the criminal code draff that overlapping with the general crimes in the criminal code will make the special crime become a general crime. It will have big impact to the authority of the Corruption Eradication Commission. It makes uncertain law condition in the law action processing.

Related to the idea above the corruption eradication commitioner, Busyro Moqoddas (2014) says that criminal code and procedure of criminal law need to be revised and easy to be understand. The people can understand that the law as a herintance of Dutch is being revising. There is not problem before the government it submited to the Representative House. Fundament subtancial parts as weak system and corruption eradication and threat the existance of corruption crime law as "lex specialis", corruption crime court, Corruption Eradication Commission and other specific reformation institutions.

By considering the changes in the capter 762 ciminal code draff, when the criminal code draft as a law without specific crime law which regulate the Corruption Eradication Commission authorities and corruption crime court in processing the crime as corruption crime. They will loss of their authorities to investigate and procecute when the new criminal law is applied. It is related to the Corruption Eradication Commission authority in investigation and procecution of the civil servant and judge corruption as a crime function.

\section{B. Chapter Formulation in the Draft of Procedure of Criminal Code}

Since the government of Indonesia ratified some conventions related to the human rights, the valid procedure of Criminal Code is not suit with the growth and the need of law of the people nowdays. Hence, the renewal of Procedure of Criminal Code is very urgent because it directly related to the process of criminal judicature.

In the procedure of criminal code was found some chapters which threaten the existency of the Eradication of Corruption Commission as the anti-corruption institution which is trusted by the people to eradicate the corruption in Indonesia, as follows:

a) Chapter 67, which gives the right to the suspect or the accused to ask for the postponement of the detention to the preface investigation judge. Basically asking for the detention postponement is the right of the suspect or the accused which had the detention, but if it is not well and measured redefined the detention in the corruption eradication commission can be postponed by the preface investigation judge. Whereas the special quality of the Corruption Eradication Commission among the law inforcer institutions is that they had never accepted the asking of postponement of detention. 
b) Chapter 75 states that the cetiment must be on the preface investigation judge permission. The rule will hinder the corruption eradication commission to cite the things that should be cited immediately, but the preface investigation judge do not accept the corruption eradication commission request. In the general injustice case, it has no difference, but in the investigation of special crime like corruption this very important to arrest the suspect with the proof on hand.

c) Chapter 83, states that the corruption eradication commission investigate the suspect under the permission of the preface investigation judge. This rule has been tried to include to the code which relate to the criminal jurisdiction process, in the purpose of weakening the corruption eradication right to eliminate the corruption crime. But this, get defiance from the law academician and form the non-government organization as it will weaken the corruption eradication commission. When this rule includes in the criminal procedure code, the the corruption eradication commission can not arrest the suspect as easy as usual, since they have to have permission from the judge for tapping the suspect. In this case they have to arrest the suspect fast and secretly. It is out of question if the corruption eradication commission needs to tap the suspect under the court permission; on the other hand the suspect is a judge or other government employee.

Based on the discussion above, as Zulkarnain, a commosioner of the corruption eradication commission, (2014) states that there are some statements in the draft of the criminal procedure code which weaken the corruption eradication commission, they are in arresting the suspect must be under the preface investigation permission, exclude the unguilty evidence, the duration of jail is only 5 days, while to solve the case need more time for the case is very complex. The right to investigate is skipped over and the preface investigation judge can stop the investigation and the prosecution of the corruption crime. The whole determination will absolutely weaken or even dismiss the corruption eradication commission.

\section{Conclusion}

\section{CONCLUSION AND SUGGESTION}

It is very urgent to reform the criminal law, because it has become the Indonesian hopes. But unification and codification effort in the crime law has to be done pricecisly and comprehenshiply. It has not implication toward the corruption eradication commission as a legal institution which has great authority because it has handled the corruption crime which becomes extra ordinary crime. In the formulation of the draft of criminal code shows the political will. Government did not pay attention seriously to enforce the corruption eradication commission authority or reverse.

\section{Suggestion}

Government and Representative House revise the criminal code draft and the criminal procedural code, especially for the law material which related to the corruption and corruption eradication commission authority. It will produce great institution which can eradicate the corruption crime and create the new criminal law.

\section{REFERENCES}

Artidjo Alkotsar, (21 September 2014), Justice was in the Heart, Jakarta, Kompas.

Ekaputra, Muhammad and Abdul Khair, (2010), System in the Criminal Code and the Criminal the Arrangement of the Criminal Code According to the New Concept, Medan, USU Press.

Fletcher, George P., (2000), Rethinking Criminal Law, Oxford University Press, Oxford. 
Rneggong, R. (2015).The Existence of Corruption Eradication Commission in the Criminal Law Reform in Indonesia. Advances in Social Sciences Research Journal, 2(2) $190-196$

Go Lisnawati, (2013), The Other Crime-Related Corruption In Questioning Authority Draft Bill and the Corruption Eradication Commission, Papers, Surabaya.

Corruption Eradication Commission (KPK), (2014), Annotation GLARE CORRUPTION and Other Related to Corruption In Draft Criminal Code offense, Jakarta.

Muladi, (February 24, 1990), Projection Material Indonesian Criminal Law in the Future, Conservation As a Professor of Criminal Law of the Faculty of Law, University OF DIPONEGORO, and SEMARANG.

Prasetyo, True and Barkatullah Abdul Halim, (2005), Politics of Criminal Law, Library Student, Yogyakarta.

Pujiyono, (2013), Models and Policy Formulation offense Codification And Corruption in the Draft Bill, paper, Corruption Eradication Commission, Medan.

Sholehuddin, M (2013), Concept of Corruption As Extraordinary Crime In the Draft Bill and Its Implication to the Corruption Eradication, paper, KPK, Surabaya.

United Nations Convention Against Corruption, (2003).

Review of the Implementation of the United States Convention against Corruption, Implementation Review Group, Third Session, Vienna, and 18-22 June 2012.

Law Number 30 Year 2002 about Corruption Eradication Commission

Code of the Criminal Law

Law No. 8 of 1981 ABOUT CODE of Criminal Procedure

Law No. 31 of 1999 about Corruption Crime Eradication

Law Number 20 of 2001 concerning Amendment to Law Number 311999 about Corruption Crime Eradication.

Draft Code of Criminal Law, 2012.

Draft Code OF CRIMINAL LAW PROCEDURE 2012. 